\title{
Energy audit of the residential building
}

Małgorzata SIKORA, Krystian SIWEK

DOI: 10.30464/jmee.2018.2.4. 317

Cite this article as:

Sikora M., Siwek K. Energy audit of the residential building. Journal of Mechanical and Energy Engineering, Vol. 2(42), No. 4, 2018, pp. 317-328.

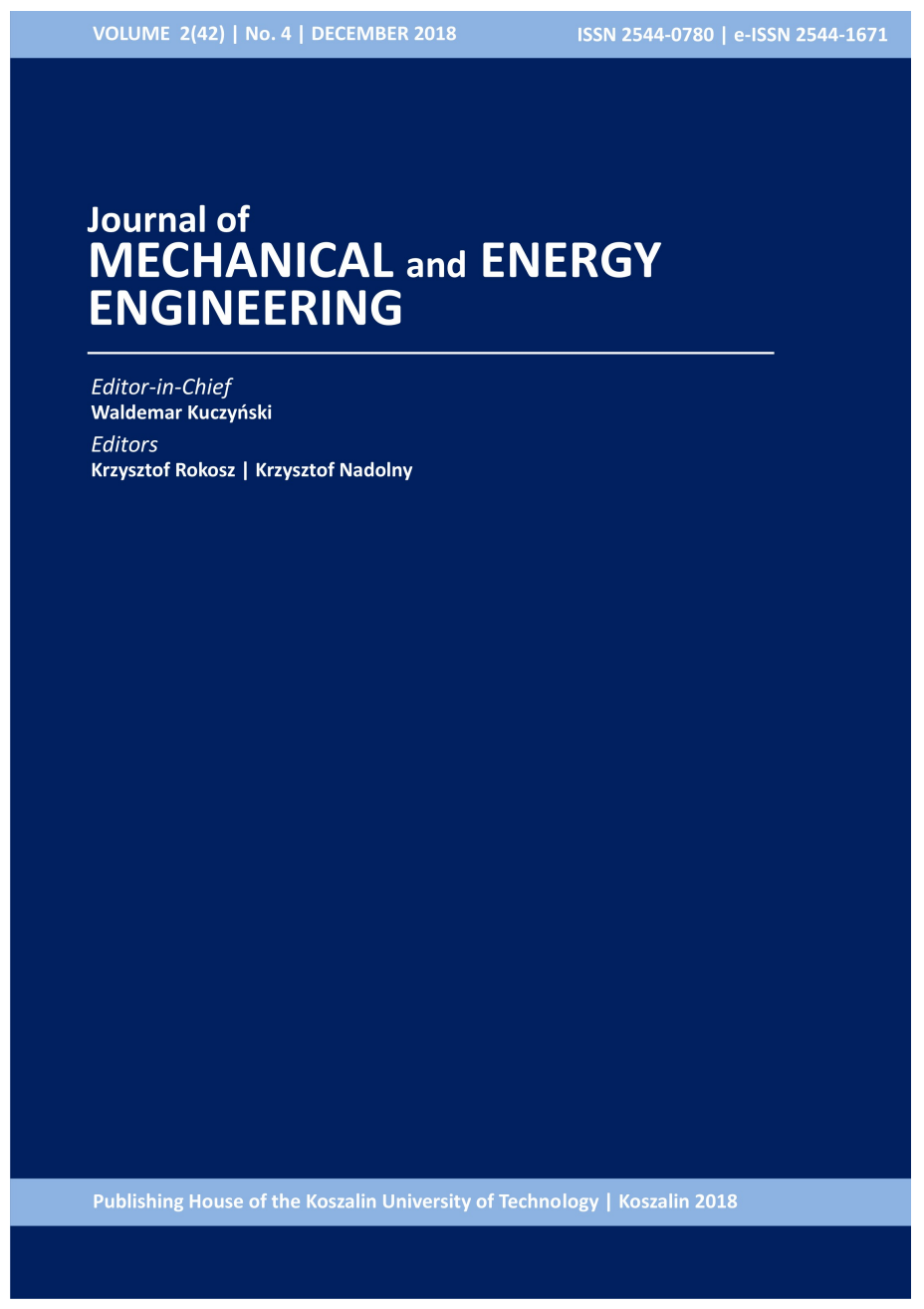

Journal of Mechanical and Energy Engineering

Website: jmee.tu.koszalin.pl

ISSN (Print): 2544-0780

ISSN (Online): 2544-1671

Volume: 2(42)

Number: 4

Year: 2018

Pages: $317-328$

Article Info:

Received 2 November 2018

Accepted 14 December 2018

\section{Open Access}

This article is distributed under the terms of the Creative Commons Attribution 4.0 (CC BY 4.0) International License (http://creativecommons.org/licenses/by/4.0/), which permits unrestricted use, distribution, and reproduction in any medium, provided you give appropriate credit to the original author(s) and the source, provide a link to the Creative Commons license, and indicate if changes were made. 


\title{
ENERGY AUDIT OF THE RESIDENTIAL BUILDING
}

\author{
Małgorzata SIKORA $^{1^{*}}$, Krystian SIWEK $^{1}$, \\ ${ }^{1 *}$ Faculty of Mechanical Engineering, Department of Energy, Koszalin University of Technology, Raclawicka \\ 15-17, 75-620, Koszalin, Poland, e-mail: malgorzata.sikora@tu.koszalin.pl
}

(Received 2 November 2018, Accepted 14 December 2018)

\begin{abstract}
One of the ways to reduce the energy consumption from conventional sources is the introduction of an energy audit, which aims to inform the owner / user of a building about its energy consumption and possible ways of its reduction. For this purpose, the coefficients EK (annual demand for final energy) and EP (the amount of non-renewable primary energy to satisfy the energy needs of the building) were introduced. Their maximum values are deter-mined in accordance with the regulations of the Minister of Infrastructure for each type of building covered by the energy audit obligation. Audit is an expertise designed to gain knowledge about energy consumption in a given building, a set of buildings, a system or an installation. It is to provide information on how to save an energy and their results. The following article presents the purpose and methodology of performing the energy audit for residential buildings.
\end{abstract}

Keywords:energy audit, primary energy EP, final energy EK, energetic efficiency, methodology

\section{INTRODUCTION}

Audit is an expertise designed to gain knowledge about energy consumption in the building, a set of buildings, a farm or an installation. It should provide information about ways of energy savings and their results. Performing an energy audit is called auditing. It is a set of activities covering the assessment of the existing state of energy use in the investigated building. A person who performs this type of audit is called an energy auditor. He is a specialist in the scope of technical means of saving energy and environmental protection as well as in the field of economic efficiency assessment of energy-saving investments, working as an independent, objective adviser $[1,2,16]$. It is import ant to be noted that the auditor is treated as an expert. His task, except the assessment of the existing state, is to propose the ways of saving energy, providing approximate costs of their introduction and the resulting profits.

One of the ways to reduce the costs of obtaining energy is the use of renewable energy sources. This direction of the power engineering is more popular for some time due to the innovativeness of this type of energy generation. What is more, it is a cost-effective method for people using buildings in which renewable energy sources are used. In addition, the European Union insists on development of RES in accordance with Directive 2009/28 / EC [4, 6]. The emphasize of the European Union is related to the amount of $\mathrm{CO}_{2}$ emitted during energy production, which affects the deterioration of the natural environment state around the world from one year to another. High emission of greenhouse gases affects the growth of the ozone hole. This directive aims to completely reduce the consumption of energy from conventional sources by $20 \%$. At the same time, this goals have been broken down into the partial-goals at the national levels, taking into account different starting positions of individual Member States [3]

Similarly to the White Book, the European Commission emphasizes in the directive the necessity to undertake actions to protect the environment, mitigate climate change and to fulfill the global RES target set by the White Book. In this case, it should be achieved by in-creasing energy production from renewable energy sources. In addition to the assumption of $20 \%$ of energy from renewable sources, the aim of the directive was also to reduce green-house gas emissions by $20 \%$ [8].

One of the ways to reduce energy consumption from conventional sources is the introduction of an energy audit, which aims to inform the owner / user of a building about its energy consumption and possible ways of its reduction. For this purpose, coefficients EK (annual demand for final energy) and EP (the amount of non-renewable primary energy to meet the energy needs of the building) were introduced. Their 
maximum values are deter-mined in accordance with the ordinances of the Minister of Infrastructure $[7,10,11]$ for each type of building covered by the energy audit obligation.

The energy audit is performed by a person called an auditor in the form of a detailed report. There are currently various types of audits that can be divided as follows:

- due to the level of detail:

- preliminary,

- detailed,

- due to the position of the ordering person:

- for the user (investor),

- for the bank,

- due to the scope:

- fragmentary (for a separate installation),

- detailed (covering the entire facility and all issues related to it),

- due to the contractor:

- performed by an auditor,

- performed by an user (eg. in the case of mass shares),

- depending on the facility on which the audit is carried out:

- a residential building,

- industrial facility,

- energy management of the community.

\section{METHODOLOGY FOR CONDUCTING AN ENERGY AUDIT}

The methodology of conducting the energy audit together with the example of energy performance certificates are presented in the Regulations of the
Minister of Infrastructure [4,10,11]. These documents contain detailed formulas for determining the energy demand for specific purposes throughout the year.

The determination of energy efficiency can be divided into four stages. The individual stages are illustrated and described in the diagram shown in Figure 1. The first one consists in analyzing the current state of affairs. Depending on the type of audit, this stage will vary in steps of proceeding. If it is an audit of a designed building, calculations of the demand for particular types of energy should be carried out based on project data obtained from the investor. This type of audit is aimed at checking the compliance of the project with the requirements for newly constructed buildings.

In the case of an existing building (renovation audit), the procedure in stage I involves systematic collection of data, inspections of the tested object condition (analysis of thermal bridges and leaks in eg. using infrared camera) and consumption of media using various types of meters and sensors. Water, gas and electricity bills are also helpful in the analysis, allowing to determine the consumption of energy carriers and, as a result, the consumption of energy. In addition, reviewed should be to building partitions, the installation and the heat sources. The second stage of the audit is to determine the reliability of the data obtained. It consists in verifying the obtained data, determining the final energy consumption and primary energy from non-renewable sources. These values, after made the calculations are compared with limit values of EK and EP coefficients for a given type of building [13].

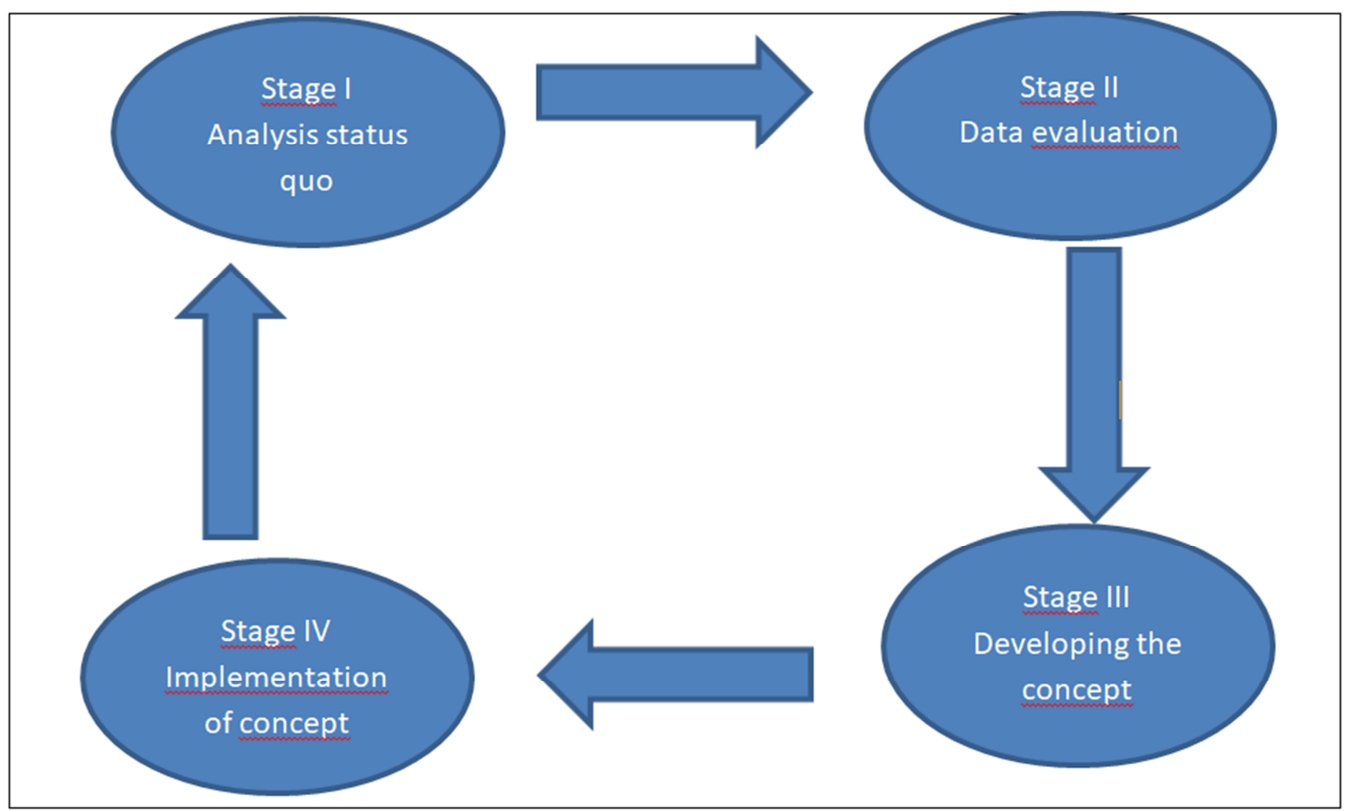

Fig. 1. The ideological scheme of methodology during proceeding of the energy audit of a building or its part [12] 
Based on the audit results, the auditor is required to present several optional concepts that will allow the reduction of the EK and EP coefficients, presenting the results of the implementation of the concept, its costs and the possibility of co-financing from various sources. The next step is developing the concept. It consists in considering hypothetical threats in its implementation. Typical obstacles that interfere with the development of the concept are the lack of technical knowledge, negligible market knowledge, lack of time (unavailable contractors), lack of capital, limited information of decision makers, energy and technology costs, unallocated fixed costs. The last step is to implement the chosen concept. In the case of an enterprise, it proceeds according to the following stages: changing the company's vision in the area of energy, improving the energy management system, motivating and sensitizing employees, monitoring and controlling the energy management system [12].

\subsection{Calculation of energy demand}

The main values in the energetic audit of a singlefamily house are the demand of energy for heating and hot water preparing. The demand for usable energy for cooling and lighting in the case of a single-family home may be omitted. The cooling demand is calculated only if there is a cooling installation that supports more than one room, and for lighting purposes only in public buildings. Calculations aimed at determining the annual demand for final energy should be made as a ratio of the demand for usable energy (which is determined by a heat balance of building) by the seasonal efficiency of a given technical system. The calculations are aimed at estimation the demand of energy for heating purposes and are given by equation (1):

$$
Q_{K, H}=\frac{Q_{H, n d}}{\eta_{H, t o t}}\left[\frac{k W h}{\text { year }}\right],
$$

where:

$Q_{K, H}-$ demand for usable energy (useful heat) for the building (residential premise) for heating, [kWh/ year], $\eta_{H, t o t}-$ average seasonal overall efficiency of the building's heating system.

In addition to the energy required for heating purposes, the preparation of hot water should also be taken into account using the dependence (2):

$$
Q_{K, W}=\frac{Q_{W, n d}}{\eta_{W, t o t}}\left[\frac{\mathrm{kWh}}{\mathrm{year}}\right],
$$

where:

$Q_{W, N d}$ - demand for useful heat to prepare hot water, [kWh/ year], $\eta_{W, \text { tot }}$ - average seasonal total efficiency of the hot water preparation system.

All the formulas described so far lead to the calculation of the most important coefficient EK and EP. The final energy demand coefficient is calculated from the dependence (3):

$$
E K=\frac{Q_{K, H}+Q_{K, W}}{A_{f}}\left[\frac{\mathrm{kWh}}{\mathrm{m}^{2} \cdot \text { year }}\right],
$$

where:

$A_{f}$ - heating or cooling area (with regulated temperature) of building or local, $\left[\mathrm{m}^{2}\right]$.

The coefficient of primary energy demand is calculated using the annual primary energy demand, which is the sum of energy demand for:

- heating,

- hot water preparation,

- cooling and ventilation for cooling rooms,

- lighting.

EP coefficient of the annual primary energy demand is calculated from the dependence (4):

$$
E P=\frac{Q_{p}}{A_{f}}\left[\frac{\mathrm{kWh}}{\mathrm{m}^{2} \cdot \text { year }}\right],
$$

where:

$A_{f}$ - heating or cooling area (with regulated temperature) of building or local, $\left[\mathrm{m}^{2}\right] . Q_{p}$ - annual demand for primary energy.

The annual demand is calculated from formula (5):

$$
Q_{p}=Q_{P, H}+Q_{P, W}+Q_{P, C}+Q_{P, L}\left[\frac{\mathrm{kWh}}{\text { year }}\right],
$$

where:

$Q_{P, H}$ - annual demand for primary energy through the heating and ventilation system for heating and ventilation, [kWh / year], $Q_{P, W}-$ annual primary energy demand by the system for preparing hot water, $\left[\mathrm{kWh} /\right.$ year], $Q_{P, C}$ annual demand for primary energy through a cooling and ventilation system for room and air cooling, [kWh / year], $Q_{P, L}$ annual primary energy demand by a lighting system (only included in public buildings), [kWh / year] [8].

\subsection{Energy demand of the building (gains and losses)}

To determine the energy demand of the building, the energy balance of the building should be made. Taking into account the direction of the flow of energy balance components, they are divided into gains and losses. To the gains are included energy provided by the heat transfer through divisions, solar energy from insolation of transparent divisions in the form of windows, glazing or doors, and insolation of opaque partitions, energy from people in the room, thermal energy being a side effect of mechanical and electronic working devices located in the room. Energy losses include losses due to heat transfer through the partitions (winter), ventilation, and transmission losses (networks and installations) [8].

The pie chart presented in Fig. 2 shows the distribution of energy components brought to a singlefamily home. The largest part of the supplied energy is from fuel, then from the sun, and on the end energy of the person and the device. The largest part of the energy supplied is obtained due to the use of high 
energy raw material (fuel) or depending on the type of installation, from the use of electricity. The effect of using this energy is its conversion into the form of thermal energy. Solar energy is a much smaller percentage of energy in relation to fuel, most often it comes from insolation of transparent divisions.

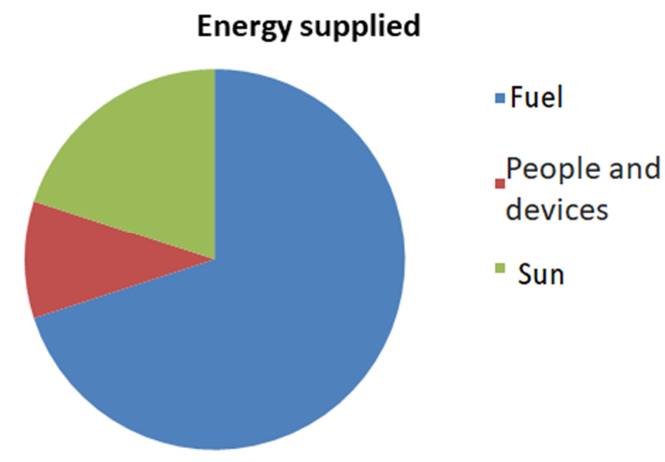

Fig. 2. Distribution of energy components supplied in the average house with an energy demand index of $150 \mathrm{kWh} /(\mathrm{m} 2 \mathrm{a})$, according to Reinmuth [9]

Fig. 3 presents a pie chart of thermal energy loss in a single-family home. The biggest part of losses comes from windows. These losses can be aggravated by the wrong selection of windows and their incorrect placement. In order to minimize heat loss through the windows, the spaces between the glass are filled with gas, in eg. argon. However, the most heat is conducted through the window frames.

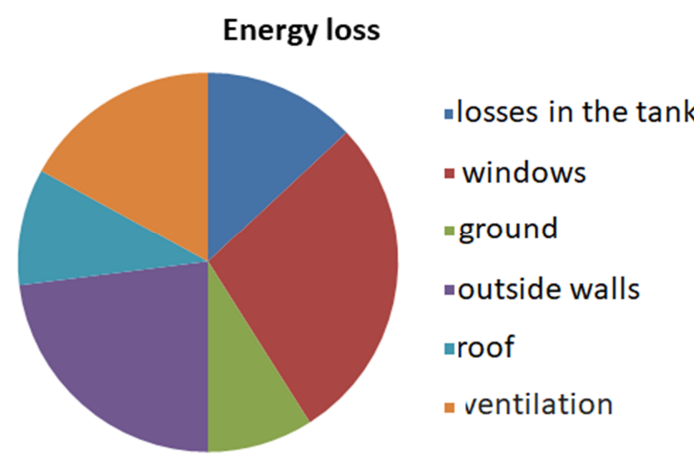

Fig. 3. Distribution of components of energy losses in the average home with an energy demand index of $150 \mathrm{kWh} /(\mathrm{m} 2 \mathrm{a})$, according to Reinmuth [9]

According to Fig.3, heat transfer through the partitions is the second largest heat loss. To reduce the amount of heat losses due to this, it is necessary to compensate thermal bridges and increase the thickness of wall insulation. There is a problem regarding the identification of a thermal bridge in a building partition. To detect thermal bridge, an infrared camera can be used. The higher the temperature difference between the inside of the house and the outside environment, the more visible is the bridge on the thermovision image. Therefore, the most favorable time of year for this type of diagnostics is winter.

Currently, the audit can be carried out using specialized programs such as ArCADIATERMOCAD from Intersoft, which allows to enter geometry and thermal parameters of the building and individual rooms in order to make a thermal balance of the building. The pro-gram contains climate data for individual zones of the country. The program also has an option to model the building in 3D where it has the ability to determine the thickness of the walls and the number of storeys, etc. The audit aims to improve the energy efficiency that can be obtained through thermomodernization projects. Examples are: the improvement, which reduces the energy demand for heating and hot water preparing in residential buildings, complexes of buildings and buildings owned by local government units.

Another goal is to reduce the consumption of primary non-renewable energy. This objective can be obtained by making a technical connection to a centralized heat source, due to the liquidation of the local heat source, resulting in a reduction in the cost of acquiring heat delivered to the buildings. Another method is the total or partial change of energy sources to renewable sources or the use of high-efficiency cogeneration [15]. Figures 4 and 5 present the printout of the calculation results of the final energy demand coefficient EK, usable energy coefficient EU and nonrenewable primary energy coefficient EP from the ArCADia-TERMOCAD program. The printout also includes a graph of the permissible value of the EP coefficient. The figures show the results of an energy audit for the same building taking into account different energy sources. In the audit presented in Fig. 4, the coal-fired boiler was assumed as the source of heat, and the biomass boiler was used In building from figure 5 .

Figure 6-9 shows the printout of selected pages of the energy audit for the above-described building with a biomass boiler as a source of heat. The document contains, in addition to building data and calculated values of EK, EU and EP coefficients, the results of heat transfer coefficient $U$ calculation for individual partitions as well as calculations for individual heating systems. 
Wskaźnik rocznego zapotrzebowania na nieodnawialną energię pierwotna EP [kWh/(m².rok)]

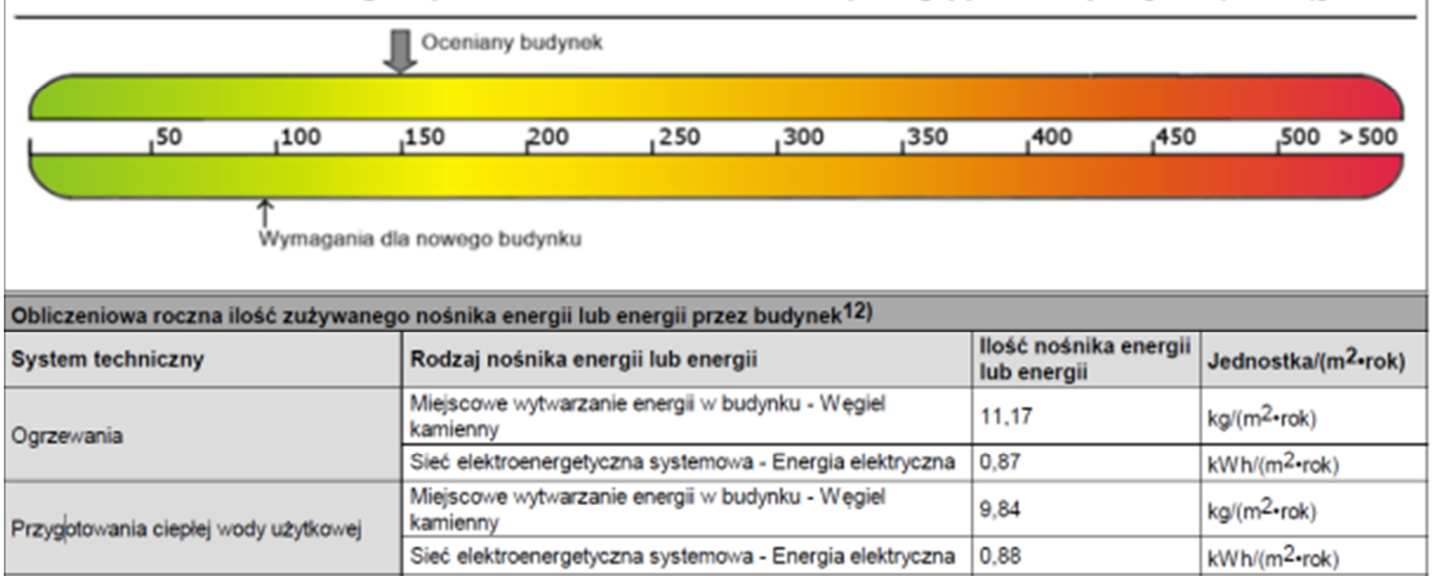

Fig. 4. Printout of an energy audit fragment from the ArCADia-TERMOCAD program for a building with a coal-fired boiler

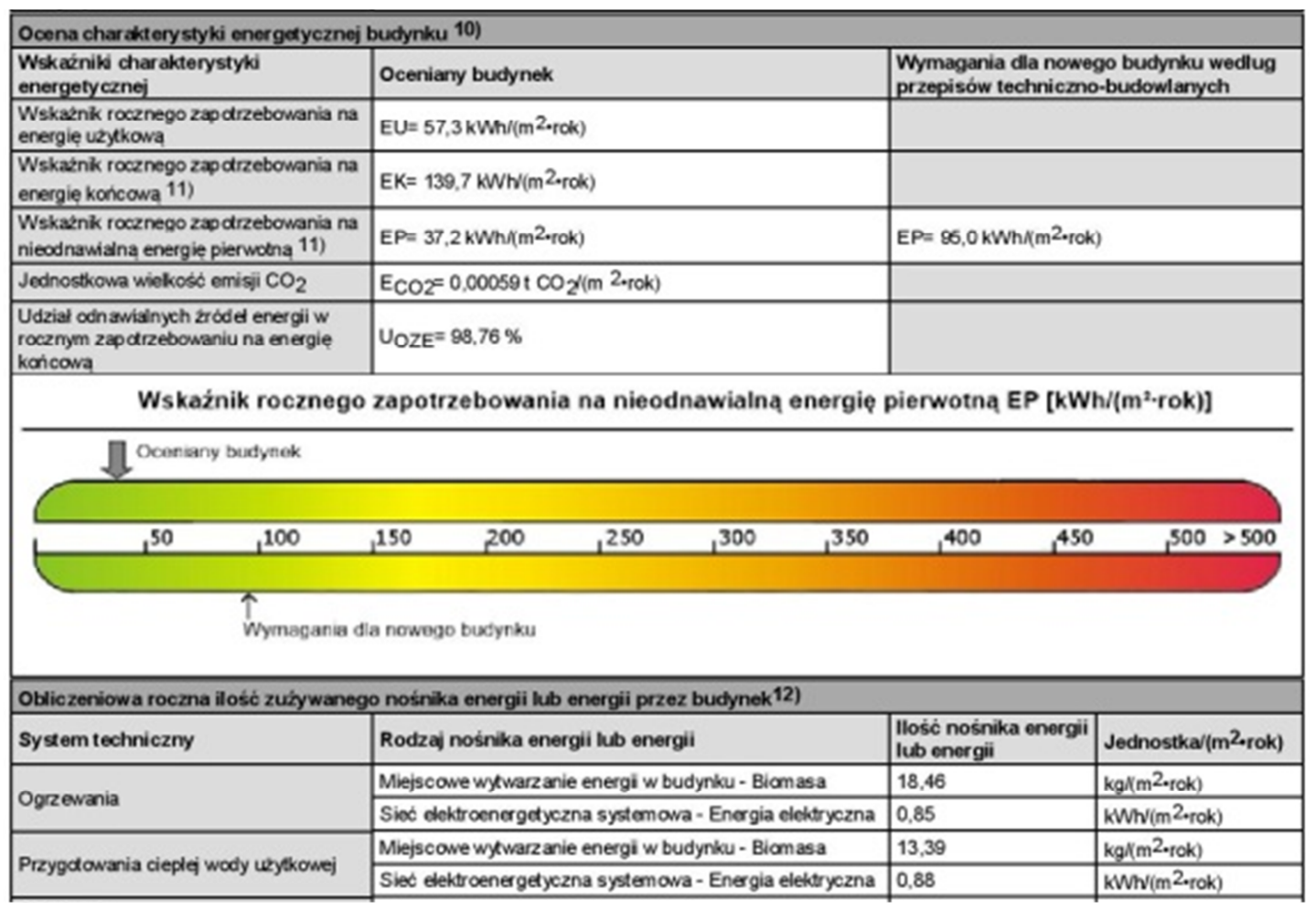

Fig. 5. Printout of an energy audit fragment from the ArCADia-TERMOCAD program for a building with a biomass boiler 
SWIADECTWO CHARAKTERYSTYKI ENERGETYCZNEJ BUDYNKU

\begin{tabular}{ll|l}
\hline Numer świadectwa 1) & 1 \\
\hline
\end{tabular}

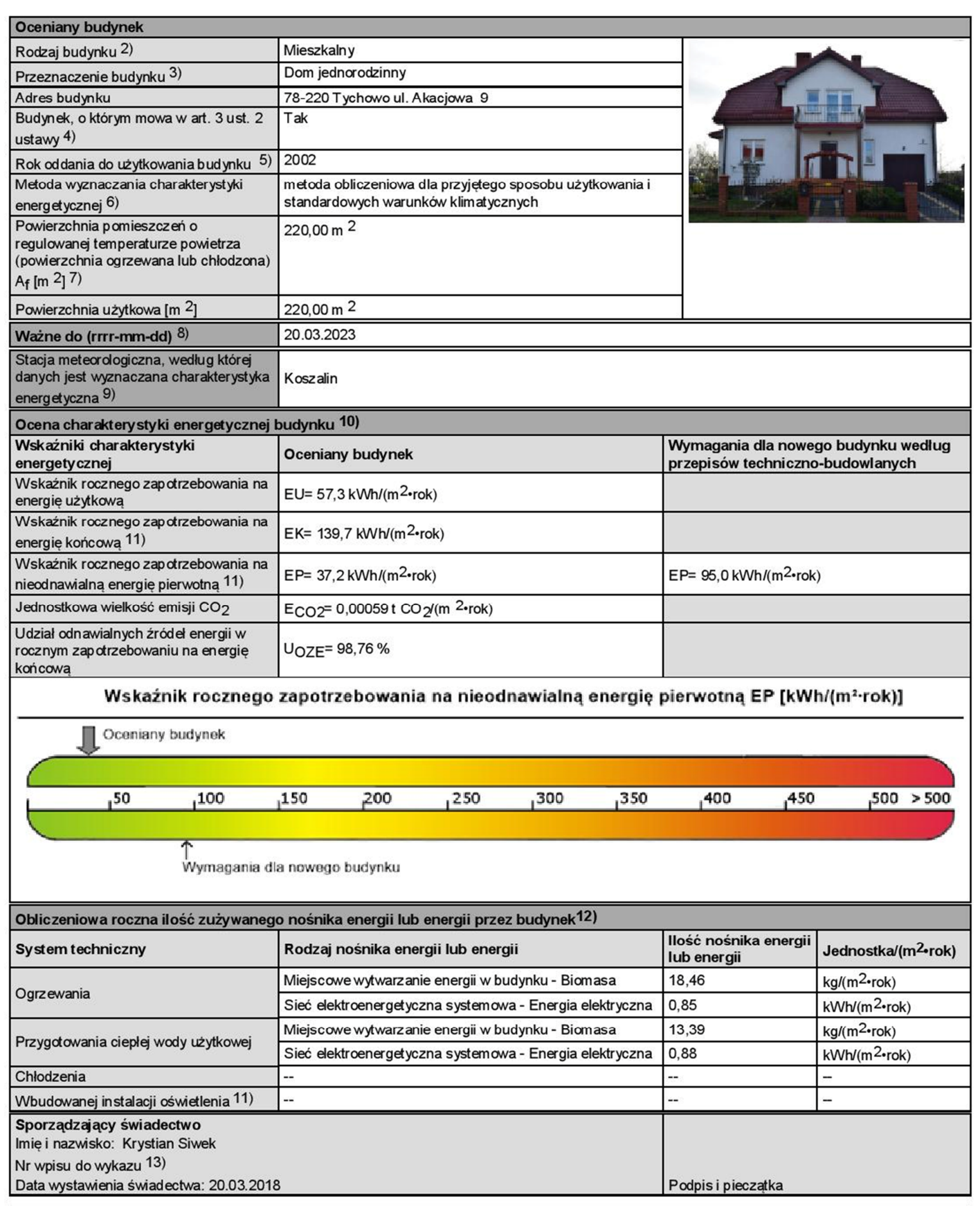

ArCADia-TERMOCAD PRO 7.0 ArCADiasoft Chudzik sp. j. ul. Sienkiewicza 85/87, 90-057 Łódż, tel (42)689-11-11, e-mail: arcadiasoft@arcadiasoft.pl, unw.arcadiasoft.pl

Licencja dla: student Krystian Siwek ;czasowa,niekomercyjna [L01]

Fig. 6. Selected cards of energy audit from the ArCADia-TERMOCAD program for a building with a biomass boiler (example 1) 
SWIADECTWO CHARAKTERYSTYKI ENERGETYCZNEJ BUDYNKU

Numer świadectwa 1) 1

\begin{tabular}{|c|c|c|c|c|}
\hline \multicolumn{5}{|c|}{ Podstawowe parametry techniczno-użytkowe budynku } \\
\hline Liczba kondygnacji budynku & \multicolumn{4}{|l|}{4} \\
\hline Kubatura budynku $\left[\mathrm{m}^{3}\right.$ ] & \multicolumn{4}{|l|}{$780,11 \mathrm{~m}^{3}$} \\
\hline $\begin{array}{l}\text { Kubatura budynku o regulowanej } \\
\text { temperaturze powietrza }[\mathrm{m} 3]\end{array}$ & \multicolumn{4}{|l|}{$780,11 \mathrm{~m}^{3}$} \\
\hline $\begin{array}{l}\text { Podzial powierzchni użytkowej budynku } \\
\text { 14) }\end{array}$ & \multicolumn{4}{|c|}{222 m powierzchni użytkowej, 78 m powierzchni nieużytkowej (strych, garaż) } \\
\hline $\begin{array}{l}\text { Temperatury wewnetrizne w budynku w } \\
\text { zależności od stref ogrzewanych }\end{array}$ & \multicolumn{4}{|c|}{$\begin{array}{l}\text { Pomieszczenia ogrzewane } 20 \text { stopni, pomieszczenia podpiwniczane nieogrzewane } 12 \text { stopni, garaż } \\
\text { ogrzewany } 12 \text { stopni, strych nieogrzewany } 12 \text { stopni. }\end{array}$} \\
\hline Rodzaj konstrukcji budynku & \multicolumn{4}{|l|}{ PBU-59 } \\
\hline \multirow[t]{14}{*}{ Przegrody budynku } & \multirow{2}{*}{ Nazwa przegrody } & \multirow{2}{*}{ Opis przegrody } & \multicolumn{2}{|c|}{$\begin{array}{l}\text { Wspólczynnik } \\
\text { przenikania ciepla } \\
\text { przegrody } U[\mathrm{~W} /(\mathrm{m} 2 \cdot \mathrm{K})]\end{array}$} \\
\hline & & & Uzyskany & $\begin{array}{l}\text { Wymagany } \\
15)\end{array}$ \\
\hline & $\begin{array}{l}\text { Balkon 90×235-Okno } \\
\text { zewnętrzne }\end{array}$ & Szerokość: $0,9 \mathrm{~m}$, Wysokość: $2,35 \mathrm{~m}$ & 0,23 & 1,10 \\
\hline & $\begin{array}{l}\text { BRAMA 240x220-Drzwi } \\
\text { zewnętrzne }\end{array}$ & Szerokość: $2,4 \mathrm{~m}$, Wysokość: $2,2 \mathrm{~m}$ & 0,00 & 1,50 \\
\hline & D 1-Dach & $\begin{array}{l}\text { Blacha trapezowa ocynkowana }(0,001 \mathrm{~m}, \lambda=50,000 \\
\mathrm{W} /(\mathrm{m} \cdot \mathrm{K})) ; \text { Łaty }(0,08 \mathrm{~m}, \lambda=0,200 \mathrm{~W} /(\mathrm{m} \cdot \mathrm{K})) ; \\
\text { Kontrlaty }(0,02 \mathrm{~m}, \lambda=0,200 \mathrm{~W} /(\mathrm{m} \cdot \mathrm{K})) ; \mathrm{Folia} \\
\text { dachowa paroprzepuszczalna }(0,002 \mathrm{~m}, \lambda=0,019 \\
\mathrm{W} /(\mathrm{m} \cdot \mathrm{K})) ; \text { Krokwie }(0,2 \mathrm{~m}, \lambda=0,200 \mathrm{~W} /(\mathrm{m} \cdot \mathrm{K})) ; \\
\text { Blacha trapezowa ocynkowana }(0,001 \mathrm{~m}, \lambda=50,000 \\
\mathrm{W} /(\mathrm{m} \cdot \mathrm{K})) ; \text { Folia dachowa paroprzepuszczalna } \\
(0,002 \mathrm{~m}, \lambda=0,019 \mathrm{~W} /(\mathrm{m} \cdot \mathrm{K})) \text {; Łaty }(0,08 \mathrm{~m}, \\
\lambda=0,200 \mathrm{~W} /(\mathrm{m} \cdot \mathrm{K}))\end{array}$ & 0,61 & 0,70 \\
\hline & $\begin{array}{l}\text { Drzwi front } 16 \text { st-Drzwi } \\
\text { zewnetrzne }\end{array}$ & Szerokość: $0,9 \mathrm{~m}$, Wysokość: $2 \mathrm{~m}$ & 0,23 & 1,50 \\
\hline & $\begin{array}{l}\text { Drzwi pirwnica 8st-Drzwi } \\
\text { zewnętrzne }\end{array}$ & Szerokość: $2,6 \mathrm{~m}$, Wysokość: $0,6 \mathrm{~m}$ & 0,45 & 1,50 \\
\hline & DW 1-Drzwi wewnẹtrzne & Szerokość: 0,9m, Wysokość: $2 m$ & 0,23 & 1,50 \\
\hline & $\begin{array}{l}\text { lazienka } 60 \times 150-0 k n o \\
\text { zewnetrzne }\end{array}$ & Szerokość: 0,6m, Wysokość: $1,5 \mathrm{~m}$ & 0,23 & 1,10 \\
\hline & $\begin{array}{l}\text { Okno dachowe } \\
70 \times 110-O \text { kno polaciowe }\end{array}$ & Szerokość: 0,7m, Wysokość: $1,1 \mathrm{~m}$ & 0,23 & 1,30 \\
\hline & PG 1-Podloga na gruncie & $\begin{array}{l}\text { Pospólka }(0,4 \mathrm{~m}, \lambda=1,950 \mathrm{~W} /(\mathrm{m} \cdot \mathrm{K})) \text {; Beton o } \\
\text { średniej gestości }(0,1 \mathrm{~m}, \lambda=1,350 \mathrm{~W} /(\mathrm{m} \cdot \mathrm{K})) \text {; Papa } \\
\text { asfaltowa na goraco }(0,002 \mathrm{~m}, \lambda=0,175 \mathrm{~W} /(\mathrm{m} \cdot \mathrm{K})) \text {; } \\
\text { Styropian }(0,2 \mathrm{~m}, \lambda=0,045 \mathrm{~W} /(\mathrm{m} \cdot \mathrm{K})) ; \text { Beton o } \\
\text { średniej gestości }(0,1 \mathrm{~m}, \lambda=1,350 \mathrm{~W} /(\mathrm{m} \cdot \mathrm{K})) \text {; Plytki } \\
\text { ceramiczne }(0,005 \mathrm{~m}, \lambda=1,300 \mathrm{~W} /(\mathrm{m} \cdot \mathrm{K}))\end{array}$ & 0,20 & 0,30 \\
\hline & $\begin{array}{l}\text { Piwnica 90x40-Okno } \\
\text { zewnętrzne }\end{array}$ & Szerokość: 0,9m, Wysokość: $0,4 \mathrm{~m}$ & 0,45 & 1,10 \\
\hline & $\begin{array}{l}\text { Poddasze-Strop } \\
\text { wewnęrzny }\end{array}$ & $\begin{array}{l}\text { Tynk lub gladż cementowo-wapienna }(0,005 \mathrm{~m}, \\
\lambda=0,820 \mathrm{~W} /(\mathrm{m} \cdot \mathrm{K})) ; \text { Plyta gipsowo kartonowa }(0,01 \\
\mathrm{m}, \lambda=0,230 \mathrm{~W} /(\mathrm{m} \cdot \mathrm{K})) ; \text { Welna mineralna } \\
\text { granulowana } 40 \quad(0,3 \mathrm{~m}, \lambda=0,050 \mathrm{~W} /(\mathrm{m} \cdot \mathrm{K})) \text {; Deska } \\
\text { Dachowa }(0,003 \mathrm{~m}, \lambda=0,033 \mathrm{~W} /(\mathrm{m} \cdot \mathrm{K}))\end{array}$ & 0,16 & 0,18 \\
\hline & $\begin{array}{l}\text { SG } 1 \text { pod ziemia -Ściana } \\
\text { na gruncie }\end{array}$ & $\begin{array}{l}\text { Tynk }(0,2 \mathrm{~m}, \lambda=0,800 \mathrm{~W} /(\mathrm{m} \cdot \mathrm{K})) ; \text { Styropian }(0,05 \\
\mathrm{m}, \lambda=0,045 \mathrm{~W} /(\mathrm{m} \cdot \mathrm{K})) ; \text { Papa asfaltowa izolacyjna gr }\end{array}$ & 0,24 & $\begin{array}{l}\text { Bez } \\
\text { wymagań }\end{array}$ \\
\hline
\end{tabular}

ArCADia-TERMOCAD PRO 7.0 ArCADiasoft Chudzik sp. j. ul. Sienkiewicza 85/87, 90-057 Łódż, tel (42)689-11-11, e-mail: arcadiasoft@arcadiasoft.pl, diasoft.pl

Licencja dla: student Krystian Siwek ;czasowa,niekomercyjna [L01]

Fig. 7. Selected cards of energy audit from the ArCADia-TERMOCAD program for a building with a biomass boiler (example 2) 
SWIADECTWO CHARAKTERYSTYKI ENERGETYCZNEJ BUDYNKU Numer świadectwa 1)

\begin{tabular}{|c|c|c|c|c|}
\hline & wewnẹtrzna & $\begin{array}{l}\lambda=0,820 \mathrm{~W} /(\mathrm{m} \cdot \mathrm{K})) ; \text { Bloczek betonowy komórkowy } \\
590 \times 120 \times 240(0,12 \mathrm{~m}, \lambda=0,140 \mathrm{~W} /(\mathrm{m} \cdot \mathrm{K})) ; \text { Tynk } \\
\text { lub gladż cementowo-wapienna }(0,02 \mathrm{~m}, \lambda=0,820 \\
\mathrm{W} /(\mathrm{m} \cdot \mathrm{K}))\end{array}$ & & \\
\hline & $\begin{array}{l}\text { SW } 24 \mathrm{~cm} \text {-Ściana } \\
\text { wewnẹtrzna }\end{array}$ & $\begin{array}{l}\text { Tynk lub gladź cementowo- wapienna }(0,02 \mathrm{~m}, \\
\lambda=0,820 \mathrm{~W} /(\mathrm{m} \cdot \mathrm{K})) ; \text { Bloczek betonowy komórkowy } \\
590 \times 240 \times 240(0,24 \mathrm{~m}, \lambda=0,140 \mathrm{~W} /(\mathrm{m} \cdot \mathrm{K})) ; \\
\text { Styropian } 10(0,1 \mathrm{~m}, \lambda=0,045 \mathrm{~W} /(\mathrm{m} \cdot \mathrm{K})) ; \text { Tynk lub } \\
\text { gladż cementowo-wapienna }(0,02 \mathrm{~m}, \lambda=0,820 \\
\mathrm{W} /(\mathrm{m} \cdot \mathrm{K}))\end{array}$ & 0,24 & 0,30 \\
\hline & Sypialnia $180 \times 150$ & Szerokość: 1,8m, Wysokość: $1,5 \mathrm{~m}$ & 0,23 & 1,10 \\
\hline & $\begin{array}{l}\text { SZ } 1 \text { parter I pietro -Ściana } \\
\text { zewnętrzna }\end{array}$ & $\begin{array}{l}\text { Tynk strukturalny Cersit CT 36-ziarno } 2,0 \mathrm{~mm} \\
(0,002 \mathrm{~m}, \lambda=1,000 \mathrm{~W} /(\mathrm{m} \cdot \mathrm{K})) ; \text { Styropian }(0,15 \mathrm{~m} \text {, } \\
\lambda=0,045 \mathrm{~W} /(\mathrm{m} \cdot \mathrm{K})) ; \text { Bloczki betonowy komórkowy } \\
590 \times 240 \times 240(0,24 \mathrm{~m}, \lambda=0,190 \mathrm{~W} /(\mathrm{m} \cdot \mathrm{K})) ; \text { Tynk } \\
\text { ceramiczno-wapienny }(0,02 \mathrm{~m}, \lambda=0,820 \mathrm{~W} /(\mathrm{m} \cdot \mathrm{K}))\end{array}$ & 0,21 & 0,23 \\
\hline & $\begin{array}{l}\text { SZ nad ziemia } \\
\text { piwnica-Ściana zewnętrzna }\end{array}$ & $\begin{array}{l}\text { Tynk mozaikowy }(0,002 \mathrm{~m}, \lambda=0,300 \mathrm{~W} /(\mathrm{m} \cdot \mathrm{K})) ; \\
\text { Styropian }(0,1 \mathrm{~m}, \lambda=0,045 \mathrm{~W} /(\mathrm{m} \cdot \mathrm{K})) ; \text { Papa } \\
\text { asfaltowa izolacyjna gr } 5 \mathrm{~mm}(0,005 \mathrm{~m}, \lambda=0,180 \\
\mathrm{W} /(\mathrm{m} \cdot \mathrm{K})) ; \text { Bloczek fundamentowy betonowy }(0,24 \\
\mathrm{m}, \lambda=0,090 \mathrm{~W} /(\mathrm{m} \cdot \mathrm{K})) ; \text { Tynk wapienno-piaskowy } \\
(0,02 \mathrm{~m}, \lambda=0,800 \mathrm{~W} /(\mathrm{m} \cdot \mathrm{K})) ; \mathrm{Glad} z \\
\text { cementowo-wapienna }(0,005 \mathrm{~m}, \lambda=0,820 \mathrm{~W} /(\mathrm{m} \cdot \mathrm{K}))\end{array}$ & 0,20 & 0,23 \\
\hline & | Tarasowe 180x235- & Szerokość: $1,8 \mathrm{~m}$, Wysokość: $2,35 \mathrm{~m}$ & 0,23 & 1,10 \\
\hline & Wykusz 236x150- & Szerokość: 2,36m, Wysokość: 1,5m & 0,23 & 1,10 \\
\hline & Wykusz boczne 90x150- & Szerokość: 0,9m, Wysokość: $1,5 \mathrm{~m}$ & 0,23 & 1,10 \\
\hline \multirow[t]{6}{*}{ System ogrzewania 16) } & $\begin{array}{l}\text { Elementy skladowe } \\
\text { systemu }\end{array}$ & \multicolumn{2}{|l|}{ Opis } & $\begin{array}{l}\text { Średnia } \\
\text { sezonowa } \\
\text { sprawność }\end{array}$ \\
\hline & \multicolumn{4}{|c|}{ Nazwa źródla ciepla: Nowe źródło ogrzewania } \\
\hline & Wytwarzanie ciepla & \multicolumn{2}{|c|}{$\begin{array}{l}\text { Kotly na biomase (sloma), wrzutowe, } z \text { obslugą ręczna, o mocy } \\
\text { do } 100 \mathrm{~kW}\end{array}$} & 0,60 \\
\hline & Przesyl ciepla & \multicolumn{2}{|c|}{$\begin{array}{l}\text { C.o. wodne z lokalnego źródła ciepla usytuowanego w } \\
\text { ogrzewanym budynku z zaizolowanymi przewodami, armaturą i } \\
\text { urządzeniami, które są zainstal owane w przestrzeni ogrzewanej }\end{array}$} & 0,96 \\
\hline & Akumulacja ciepla & \multicolumn{2}{|c|}{$\begin{array}{l}\text { Zasobnik ciepla w systemie ogrzewania o parametrach } 70 / 55^{\circ} \mathrm{C} \\
\text { w przestrzeni ogrzewanej }\end{array}$} & 0,93 \\
\hline & $\begin{array}{l}\text { Regulacja i wykorzystanie } \\
\text { ciepla }\end{array}$ & \multicolumn{2}{|c|}{$\begin{array}{l}\text { Ogrzewanie wodne z grzejnikami czlonowymi lub plytowymi w } \\
\text { przypadku regulacji centralnej bez automatycznej regulacji } \\
\text { miejscowej }\end{array}$} & 0,77 \\
\hline \multirow[t]{5}{*}{$\begin{array}{l}\text { System przygotowania cieplej wody } \\
\text { użytkowej 16) }\end{array}$} & $\begin{array}{l}\text { Elementy skladowe } \\
\text { systemu }\end{array}$ & \multicolumn{2}{|l|}{ Opis } & $\begin{array}{l}\text { Średnia } \\
\text { roczna } \\
\text { sprawność }\end{array}$ \\
\hline & \multicolumn{4}{|c|}{ Nazwa źródła ciepła: Nowe źródlo cieplej wody } \\
\hline & Wytwarzanie ciepla & \multicolumn{2}{|c|}{$\begin{array}{l}\text { Wezel cieplny kompaktowy z obudowa, o mocy nominalnej do } \\
100 \mathrm{~kW}\end{array}$} & 0,70 \\
\hline & Przesyl ciepla & \multicolumn{2}{|l|}{$\begin{array}{l}\text { Centralne podgrzewanie wody - system y z obiegami } \\
\text { cyrkulacyjnymi z pionami instalacyjnymi nieizolowanymi i } \\
\text { izolowanymi przewodami rozprowadzającymi }\end{array}$} & 0,60 \\
\hline & Akumulacja ciepla & \multicolumn{2}{|c|}{$\begin{array}{l}\text { System przygotowania cieplej wody użytkowej bez zasobnika } \\
\text { cieplej wody użytkowej }\end{array}$} & 1,00 \\
\hline System chlodzenia 16) & $\begin{array}{l}\text { Elementy skladowe } \\
\text { systemu }\end{array}$ & \multicolumn{2}{|l|}{ Opis } & $\begin{array}{l}\text { Średnia } \\
\text { sezonowa } \\
\text { sprawność }\end{array}$ \\
\hline
\end{tabular}

Fig. 8. Selected cards of energy audit from the ArCADia-TERMOCAD program for a building with a biomass boiler (example 3) 


\begin{tabular}{|l|l|l|l|l|l|}
\hline Wskażnik rocznego zapotrzebowania na energię użytkowa EU [kWh/(m 2•rok)] 17) \\
\hline & $\begin{array}{l}\text { Ogrzewanie i } \\
\text { wentylacja }\end{array}$ & $\begin{array}{l}\text { Ciepta woda } \\
\text { użytkowa }\end{array}$ & Chłodzenie & $\begin{array}{l}\text { Oświetlenie } \\
\text { wbudowane }\end{array}$ & Suma \\
\hline Suma [kWh/(m 2•rok)] & 32,99 & 24,36 & 0,00 & & 57,35 \\
\hline Udział [\%] & 57,52 & 42,48 & 0,00 & & 100,00 \\
\hline
\end{tabular}

\begin{tabular}{|l|l|l|l|l|l|}
\hline Wskaźnik rocznego zapotrzebowania na energię końcowa EK [kWh/(m 2•rok)] 17) \\
\hline $\begin{array}{l}\text { Rodzaj nośnika energii lub } \\
\text { energii }\end{array}$ & $\begin{array}{l}\text { Ogrzewanie i } \\
\text { wentylacja }\end{array}$ & $\begin{array}{l}\text { Ciepła woda } \\
\text { użytkowa }\end{array}$ & Chłodzenie & $\begin{array}{l}\text { Oświetlenie } \\
\text { wbudowane }{ }^{11)}\end{array}$ & Suma \\
\hline $\begin{array}{l}\text { Miejscowe wytwarzanie energii } \\
\text { w budynku - Biomasa }\end{array}$ & 79,98 & 58,00 & 0,00 & 0,00 & 137,98 \\
\hline $\begin{array}{l}\text { Sieć elektroenergetyczna } \\
\text { system owa - Energia } \\
\text { elektryczna }\end{array}$ & 0,85 & 0,88 & 0,00 & 0,00 & 1,73 \\
\hline Suma [kWh/(m 2.rok)] & 80,83 & 58,89 & 0,00 & 0,00 & 139,71 \\
\hline Udział [\%] & 57,85 & 42,15 & 0,00 & 0,00 & 100,00 \\
\hline Wskaźnik rocznego zapotrzebowania na energię końcowa EK: 139,71 [kWh/(m 2•rok)] & \\
\hline
\end{tabular}

\begin{tabular}{|l|l|l|l|l|l|}
\hline \multicolumn{6}{|l|}{ Wskaźnik rocznego zapotrzebowania na nieodnawialną energię pierwotną EP [kWh/(m 2•rok)] 17) } \\
\hline $\begin{array}{l}\text { Rodzaj nośnika energii lub } \\
\text { energii }\end{array}$ & $\begin{array}{l}\text { Ogrzewanie i } \\
\text { wentylacja }\end{array}$ & $\begin{array}{l}\text { Ciepła woda } \\
\text { użytkowa }\end{array}$ & Chłodzenie & $\begin{array}{l}\text { Oświetlenie } \\
\text { wbudowane 11) }\end{array}$ & Suma \\
\hline $\begin{array}{l}\text { Miejscowe wytwarzanie energii } \\
\text { w budynku - Biom asa }\end{array}$ & 16,00 & 11,60 & 0,00 & 0,00 & 27,60 \\
\hline $\begin{array}{l}\text { Sieć elektroenergetyczna } \\
\text { system owa - Energia } \\
\text { elektryczna }\end{array}$ & 2,55 & 2,65 & 0,00 & 0,00 & 5,20 \\
\hline Suma [kWh/(m 2.rok)] & 18,55 & 14,25 & 0,00 & 0,00 & 32,80 \\
\hline Udział [\%] & 56,55 & 43,45 & 0,00 & 0,00 & 100,00 \\
\hline Wskaźnik rocznego zapotrzebowania na nieodnawialną energię pierwotna EP: $37,16[\mathrm{kWh/(m} \mathrm{2.rok)]}$ \\
\hline
\end{tabular}

\footnotetext{
Zalecenia dotyczące oplacalnej ekonomicznie i wykonalnej technicznie poprawy charakterystyki energetycznej budynku w zakresie 18)

1) przegród budynku w przypadku planowania robót budowlanych polegających na ociepleniu budynku, obejmujących ponad $25 \%$ powierzchni przegród zewnętrznych tego budynku

2) system ów technicznych w budynku w przypadku planowania robót budowlanych polegajacych na ociepleniu budynku, obejmujących ponad $25 \%$ powierzchni przegród zewnętrznych tego budynku

3) przegród budynku niezależnie od planowanych robót budowlanych, o których mowa w pkt 1
}

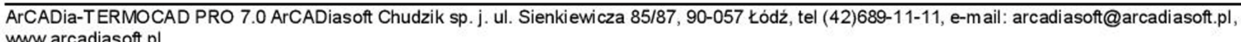

Fig. 9. Selected cards of energy audit from the ArCADia-TERMOCAD program for a building with a biomass boiler (example 4) 


\section{SUMMARY}

European Union directives are designed to force on Member States to reduce energy consumption, especially from non-renewable sources. They provide the basis and guidance for the legislation of the Member States of the European Union. Ways of achieving the set goal are not imposed on the Union, so each state has the possibility to implement projects in its own way. In Poland and in several other countries, one of the ways to achieve the goal of reducing energy consumption from non-renewable sources is to introduce energy audits of newly designed buildings as well as existing ones. The audit allows to determine if the de-signed building meets the standards related to low energy consumption set by the legislator. In the case of renovation audits, the project involves checking the condition of the building and installation, presenting ways to reduce energy consumption for heating and hot water preparing by carrying out thermo-modernization and reducing the consumption of primary non-renewable energy through the exchange of heat sources for renewable energy. On the basis of figures 4 and 5 can be determined a significant reduction of the EP coefficient value when as a heat source is using a biomass boiler. It fell by over $100 \mathrm{kWh} /\left(\mathrm{m}^{2} /\right.$ year $)$. Another indirect goal is to reduce $\mathrm{CO}_{2}$ emissions. The reduction of energy consumption for heating purposes, especially those from fossil fuels, significantly reduces the emission of greenhouse gases. In addition to economic benefits, the energy audit of the building also brings environmental benefits [14].

\section{Nomenclature}

$$
\begin{aligned}
& \text { Symbols } \\
& Q_{K, H} \quad \text { - Annual demand for final energy, }\left[\frac{\mathrm{kWh}}{\mathrm{year}}\right] \\
& Q_{H, n d} \quad \text { - demand for usable energy, }\left[\frac{\mathrm{kWh}}{\mathrm{year}}\right] \\
& \eta_{H, t o t}-\text { average seasonal overall efficiency of the } \\
& \text { building's heating system } \\
& Q_{K, W} \quad \text { - energy required for heating purposes, (the } \\
& \text { preparation of hot water, }\left[\frac{\mathrm{kWh}}{\mathrm{year}}\right] \\
& Q_{W, n d}-\text { demand for useful heat to prepare hot water, }\left[\frac{\mathrm{kWh}}{\mathrm{year}}\right] \\
& \eta_{W, \text { tot }} \text { - average seasonal total efficiency of the hot water } \\
& \text { preparation system } \\
& A_{f} \quad \text { - heating or cooling area (with regulated } \\
& \text { temperature) of building or local, }\left[\mathrm{m}^{2}\right] \text {. } \\
& Q_{p} \quad-\text { The annual demand, }\left[\frac{\mathrm{kWh}}{\mathrm{year}}\right] \\
& Q_{P, H} \quad \text { - annual demand for primary energy through the } \\
& \text { heating and ventilation system for heating and } \\
& \text { ventilation, }\left[\frac{\mathrm{kWh}}{\mathrm{year}}\right] \\
& Q_{P, W} \quad \text { - annual primary energy demand by the system for } \\
& \text { preparing hot water, }\left[\frac{\mathrm{kWh}}{\mathrm{year}}\right]
\end{aligned}
$$

$$
\begin{aligned}
Q_{P, C} \quad- & \text { annual demand for primary energy through } \\
& \text { a cooling and ventilation system for room and air } \\
& \text { cooling, }\left[\frac{\mathrm{kWh}}{\text { year }}\right] \\
Q_{P, L} \quad- & \text { annual primary energy demand by a lighting } \\
& \text { system (only included in public buildings), }\left[\frac{\mathrm{kWh}}{\text { year }}\right]
\end{aligned}
$$

$$
\begin{aligned}
& \text { Acronyms } \\
& \text { EK } \quad-\text { Final energy } \\
& \text { EP } \quad-\text { Primary energy }
\end{aligned}
$$

\section{References}

1. "Polish Energy Policy until 2030", attachment to Resolution No. 202/2009 of the Council of Ministers of November 10, 2009 (in Polish)

2. Błajszczak G .: Energy efficiency - review of regulations and standards. Polskie Sieci Elektroenergetyczne Operator S.A. (in Polish)

3. Dobrzańska B., Dobrzański G., Kiełczewski D .: Ecology and environmental protection, PWN, Warsaw 2012. (in Polish)

4. Dydenko J., Nowak K .: "Energy Characteristic and Audit of Buildings", Wolters Kluwer Polska Publisher, Warsaw 2009 (in Polish)

5. DIRECTIVE 2002/91 / EC of the European Parliament and of the Council of 16.12.2002. "on the energy performance of buildings" (OJ C213 Ez 31.7.2001 p. 266 and OJ C 203 E of 27.08.2002, p. 69, OJ C 36, 8/2.2002, p. C 107, 3.5.2002, p. 76. Opinion of the European Parliament of 6 February 2002) (in Polish)

6. Directive of the European Parliament and of the Council 2009/28 / EC of 23 April 2009 on the promotion of the use of energy from renewable sources and amending and subsequently repealing Directives 2001/77 / EC and 2003/30 / EC (in Polish)

7. Górzyński J.: "The basics of energy analysis of construction objects" Publishing hous of Warsaw University of Technology, Warsaw 2012. (in Polish)

8. Guła A., Gumuła S., Buczek A .: Guide: Renewable and unconventional energy sources, Tarbonus, Kraków 2008. (in Polish)

9. Reinmuth F.: Energiesparung in der Geba üdetechnik, Vogel Buchverlag, Wu r̈zburg 1994. (in Polish)

10. REGULATION OF THE MINISTER OF INFRASTRUCTURE dated 17 March 2009. "On the detailed scope and forms of the energy audit and parts of the renovation audit, models of audit cards, as well as the algorithm for assessing the profitability of the thermo-modernization undertaking" (Journal of Laws No. 223, item 1459) (in Polish)

11. Regulation of the Minister of Infrastructure, dated November 6, 2008. "On the methodology for calculating the energy performance of a building and a dwelling or a part of a building constituting an independent technical and operational unit and the method of drawing up and models of energy performance certificates" (Journal of Laws No. 156, item 1118) (in Polish)

12. Ulbrich $\mathrm{R}$.: Energy audit, and energy-saving house. Opole University of Technology. Opole 2001. (in Polish)

13. THE ACT of 15 April 2011 on "energy efficiency" (Journal of Laws No. 94, item 551). (in Polish)

14. THE ACT of 21 November 2008 "on supporting thermomodernization and renovation" (Journal of Laws No. 223, item 1459). (in Polish)

15. Act of November 21, 2008 on supporting thermomodernization and renovations 11.2008. (in Polish)

16. Życzyńska A .: The use of an audit and energy certificate of a building in real estate management, Construction and Architecture 12 (4) (2013) 107-116. (in Polish) 


\section{Biographical notes}

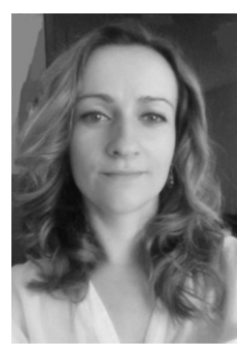

Małgorzata Sikora received her

M.Sc. degree in Environmental

Engineering (specialization: Heating and air conditioning) and next Ph.D

(with honors) degree in Machinery

Construction and Operation from

Koszalin University of Technology, in 2008 and 2011 respectively. Since 2011 she has been an assistant in the Department of Heating and Refrigeration Engineering at the Koszalin University of Technology. Currently she works as an assistant professor in Department of Power Engineering. Her scientific interests concern a heat and flow phenomenon during refrigerants condensation, refrigeration, heat pumps, etc. She has participated a in 4 national research projects, 1 international education project (Tempus Energy). She presenting results of her work at 4 international and numerous national conferences, she published 4 articles in journals from the Philadelphia list and 15 articles in national magazines and 46 papers printed in national and international conferences materials. Dr. Eng. Małgorzata Sikora is also coauthor of 1 monograph published in English, and 1 didactic textbook.

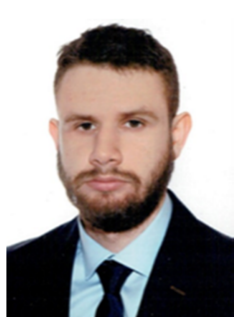

Krystian Siwek - a graduate of the Energetic on Faculty of Mechanical Engineering (specialization of Renewable Sources of Energy) at the Koszalin University of Technology. Currently, he works as a CAD designer at Buglo. Author of several articles in the journals: Busses and Refrigeration (in polish). 
